\title{
A systematic review on the efficacy and safety of eculizumab for atypical hemolytic uremic syndrome
}

\author{
Anoush Azarfar ${ }^{1}$, Mahin Ghorban Sabbagh ${ }^{2}$, Yalda Ravanshad ${ }^{3 *}$, Mohammad Esmaeeli ${ }^{1}$, Hassan Mehrad- \\ Majd $^{4}$, Azade Oveisi Sani ${ }^{1}$, Sahar Ravanshad ${ }^{5}$ \\ ${ }^{1}$ Department of Pediatrics, Faculty of Medicine, Mashhad University of Medical Sciences, Mashhad, Iran \\ ${ }^{2}$ Kidney Transplantation Complications Research Center, Mashhad University of Medical Sciences, Mashhad, Iran \\ ${ }^{3}$ Department of Community Medicine, Mashhad Branch, Islamic Azad University, Mashhad, Iran \\ ${ }^{4}$ Clinical Research Unit, Faculty of Medicine, Mashhad University of Medical Sciences, Mashhad, Iran \\ ${ }^{5}$ Department of Internal Medicine, Faculty of Medicine, Mashhad University of Medical Sciences, Mashhad, Iran
}

\section{A R T I C L E I N F O}

Article Type:

Review

\section{Article History:}

Received: 2 July 2018

Accepted: 20 November 2018

Published online: 17 December 2018

\section{Keywords:}

Thrombotic microangiopathy Atypical hemolytic uremic syndrome Eculizumab

\begin{abstract}
A B S T R A C T
Context: To date, several studies have been done regarding the treatment of atypical hemolytic uremic syndrome (aHUS) which discussed eculizumab as a potential treatment for this syndrome. However, the safety and efficacy of eculizumab were not fully assessed. This study aims to do a systematic review about the efficacy and safety of eculizumab in treatment of aHUS.

Evidence Acquisitions: An electronic literature search was conducted to identify appropriate studies. We included all randomized trials and observational studies about using eculizumab in aHUS. Two independent reviewers extracted data from the articles according to the selection criteria.

Results: Eligible studies were included in this systematic review. The literature search and reference mining yielded 571 potential relevant articles. We removed 173 articles because of duplication. We also excluded 245 articles after reviewing the titles and abstracts, and removed 61 studies because the topics were not relevant to the subject. Finally, five studies were included in the systematic review.

Conclusions: Acknowledging the limitations of the study due to the size and nature of the included studies, our systematic review shows that eculizumab was effective in the treatment of aHUS. However, further large randomized trials are suggested.
\end{abstract}

\section{Implication for health policy/practice/research/medical education:}

Eculizumab may be effective in the treatment of aHUS.

Please cite this paper as: Azarfar A, Ghorban Sabbagh M, Ravanshad Y, Esmaeeli M, Mehrad-Majd H, Oveisi Sani A. A systematic review on the efficacy and safety of eculizumab for atypical hemolytic uremic syndrome. J Renal Inj Prev. 2019;8(2):116-121. DOI: $10.15171 /$ jrip.2019.22.

\section{Introduction}

Atypical hemolytic uremic syndrome (aHUS) is a rare disease, which is usually characterized by acute kidney injury (AKI), thrombocytopenia and microangiopathic hemolytic anemia (MAHA) (2). Using suitable bacteriological, molecular and serological investigations, aHUS can be differentiated from typical HUS (Shiga toxin-producing Escherichia coli), which is related to a preceding enterohemorrhagic E. coli infection (EHEC) $(1,2)$. The atypical form of aHUS has a poor prognosis where up to $50 \%$ of cases may result in end-stage renal disease, and up to $25 \%$ of lethal outcomes progress to an acute phase (3-5). Complement dysregulation which results in glomerular endothelial cell damage is known to be a significant element in aHUS etiology (3-5). Along with possible irreversible damages to other organs due to aHUS, fast progress of thrombotic microangiopathy (TMA) is an indication of a need for urgent treatment $(6,7)$. TMA may result in acute renal dysfunction in early phases of the disease $(6,7)$. It has also been discussed that AKI and chronic kidney disease (CKD) are correlated where each one can be seen as a risk factor for the other $(6,7)$. Eculizumab (Soliris) is a monoclonal antibody which binds to $\mathrm{C} 5$ and prevents its division into C5a and C5b. Therefore, it fully blocks the formation of terminal complement complex (C5b-9) (5). Several studies done 
on patients with aHUS have mentioned the efficacy of eculizumab in the treatment of aHUS (6,8-10). Age (being younger), higher baseline $\mathrm{LDH}$ and lower baseline hemoglobin are related to the improvement of greater estimated glomerular filtration rate (eGFR) (6). Early eculizumab initiation resulted in improved renal recovery, showing the necessity of fast diagnosis and treatment of aHUS (6). Our study aims to have a systematic review about the efficacy and safety of eculizumab for aHUS.

\section{Evidence Acquisitions}

We searched PubMed, the Cochrane Library, Science Direct, Scopus, and Web of Science (updated up to October 2017). The search term was "Hemolytic Uremic Syndrome" and (eculizumab or Soliris). We scanned bibliographies in relevant articles and conference proceedings. Studies by the same author were verified for possible overlapping participant groups. If the study was reported as duplicate, only the most recent or complete study was included. The following selection criteria were applied: We included all study designs except case histories.

\section{Data extraction and quality assessment}

Two independent reviewers extracted data from the articles, according to the selection criteria. Disagreements were resolved by discussion between two reviewers considering the opinion of a third reviewer. The following information was abstracted from each included study: first author and year of publication, design of study, sample size, mean age of patients, intervention regime, follow-up duration, and outcome measures for each group. All the analysis were based on previously published studies; thus, no ethical approval or patient consent was required.

\section{Results}

Search results and characteristics

The literature search and reference mining yielded 571 potential relevant articles. We removed 173 articles because of duplication. We also excluded 245 articles after reviewing the titles and abstracts because they were books, book sections or review papers, and therefore not relevant. Then, we reviewed the full-text of selected articles and removed 61 studies because the topics were not relevant to the subject. At last, 5 studies (2,6,11-13) were included in the systematic review. The flow diagram of the study selection is given in Figure 1. Characteristics and the details of the studies are summarized in Table 1.

\section{Outcomes and adverse effects}

The summary of outcomes of our study is provided in Table 2. Efficacy of eculizumab for treatment of aHUS in most of the studies was assessed with platelet count normalization, TMA event-free status, and complete TMA response and also eGFR improvement greater than $15 \mathrm{~mL} / \mathrm{min} / 1.73 \mathrm{~m}^{2}$. Note that in Table 2, two different trials of the Lichen study each with 2-year, 1-year and 26-week follow-up have been considered. However, the conclusion of both trials was the same.

\section{Discussion}

In this systematic review, five studies were included, but none of them was a randomized control trial. Therefore, we couldn't do a quantitative synthesis (meta-analysis). In Table 2, we reported two separate entries from the Walle study (6) and six entries (sub-studies) from the Licht study (13). From Walle studies (6), the two substudies were different and were therefore provided as two entries because of their time-to-treatment from last aHUS manifestation ( $<7$ days and $>7$ days). The Licht study (13) was combined of two trials, each of them was divided into three separate entries because of different follow-up time (Table 2). Most of the reported studies were done on adult patients except for the studies by Greenbaum (14) and Sheerin et al (2), where 15 out of 43 patients were children.

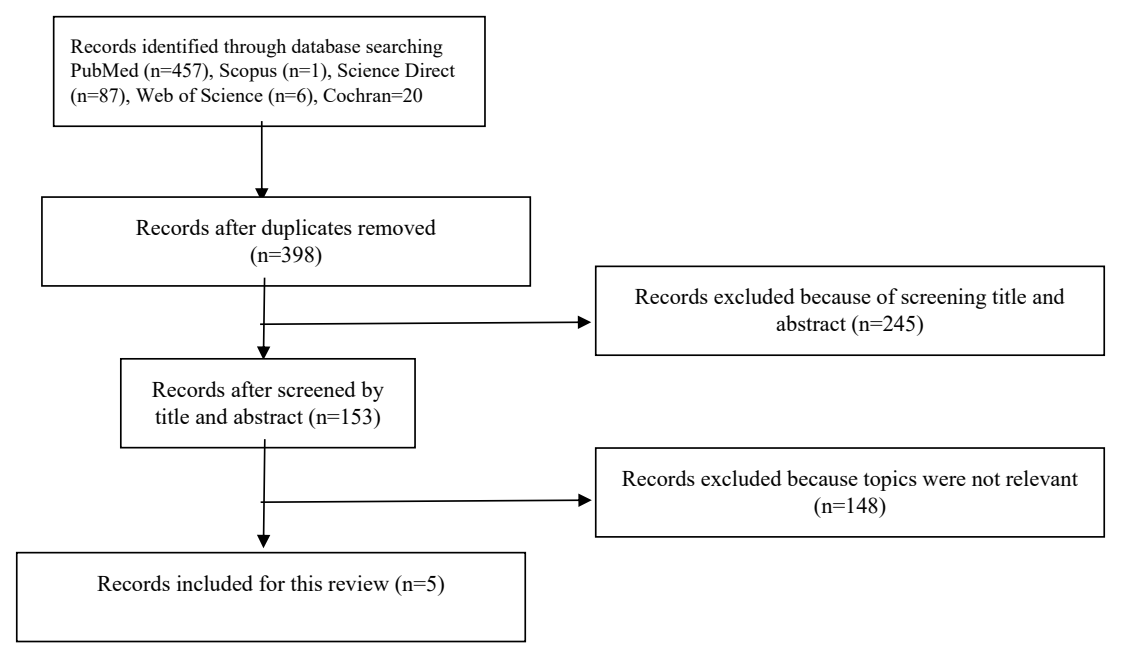

Figure 1. Flow chart of study selection process. 
Table 1. General characteristics of trials included in this systematic review

\begin{tabular}{|c|c|c|c|c|c|c|c|c|}
\hline No. & Name & Year & Design & $\begin{array}{l}\text { Sample } \\
\text { size }\end{array}$ & $\begin{array}{l}\text { MEAN age } \\
\text { (y) }\end{array}$ & $\begin{array}{l}\text { Sex (female) } \\
\text { No. (\%) }\end{array}$ & Follow-up & Intervention regime \\
\hline 1 & $\begin{array}{l}\text { Walle } \\
\text { (group 1) }\end{array}$ & 2017 & $\begin{array}{l}\text { Prospective study } \\
\text { Time to treatment from last aHUS manifestation }<7 \text { days }\end{array}$ & 21 & 30 & $11(52)$ & 1 year & Not Reported \\
\hline 2 & $\begin{array}{l}\text { Walle } \\
\text { (group 2) }\end{array}$ & 2017 & $\begin{array}{l}\text { Prospective study } \\
\text { Time to treatment from last aHUS manifestation }>7 \text { days }\end{array}$ & 76 & 29 & $49(64)$ & 1 year & Not Reported \\
\hline 3 & Fakhouri & 2016 & Trial & 41 & 406 & $28(68)$ & 1 year & $\begin{array}{l}\text { Intravenously at } 900 \mathrm{mg} \text { once a week for } \\
4 \text { weeks, } 1200 \mathrm{mg} \text { at week } 5 \text {, and then } 1200 \mathrm{mg} \text { every } 2 \text { weeks. }\end{array}$ \\
\hline 4 & Sheerin & 2016 & Descriptive & 43 & $\begin{array}{l}15 \text { were } \\
\text { children } \\
\text { and } 28 \\
\text { were adult. }\end{array}$ & 23 & 1 year & $\begin{array}{l}\text { All adult patients received an initial dose of } 900 \mathrm{mg} \text { via } 35-\mathrm{min} \text { IV infusion and then } 900 \mathrm{mg} \\
\text { every } 7 \text { days for the first } 4 \text { doses, followed by } 1200 \mathrm{mg} \text { for the fifth dose } 7 \text { days later. } \\
\text { The maintenance dose was } 1200 \mathrm{mg} \text { every } 14 \text { days. The pediatric dosing schedule was } \\
\text { adjusted according to weight }\end{array}$ \\
\hline 5 & Greenbaum & 2016 & Prospective study & 22 & 6.5 & $10(45)$ & 26 weeks & Eculizumab was administered at doses prespecified by body weight \\
\hline 7 & $\begin{array}{l}\text { Licht } 1 \\
1 \text { year }\end{array}$ & 2015 & Trial & 17 & 28 & $12(71)$ & 1 year & Not reported \\
\hline 8 & $\begin{array}{l}\text { Licht } 1 \\
26 \text { weeks }\end{array}$ & 2015 & Trial & 17 & 28 & $12(71)$ & 26 weeks & Not reported \\
\hline 9 & $\begin{array}{l}\text { Licht } 2 \\
2 \text { year }\end{array}$ & 2015 & Trial & 20 & 28 & $12(60)$ & 2 year & Not Reported \\
\hline 10 & $\begin{array}{l}\text { Licht } 2 \\
1 \text { year }\end{array}$ & 2015 & Trial & 20 & 28 & $12(60)$ & 1 year & Not reported \\
\hline 11 & $\begin{array}{l}\text { Licht } 2 \\
26 \text { weeks }\end{array}$ & 2015 & Trial & 20 & 28 & $12(60)$ & 26 weeks & Not reported \\
\hline
\end{tabular}


Table 2. Outcome of studies

\begin{tabular}{|c|c|c|c|c|c|c|c|}
\hline No. & Name & $\begin{array}{l}\text { Platelet count } \\
\text { normalization }\end{array}$ & $\begin{array}{l}\text { TMA event- } \\
\text { free status }\end{array}$ & $\begin{array}{l}\text { Complete } \\
\text { TMA response }\end{array}$ & $\begin{array}{l}\text { eGFR improvement } \\
\geq 15 \mathrm{~mL} / \mathrm{min} / 1.73 \mathrm{~m} 2\end{array}$ & Adverse effects & Conclusion \\
\hline 1 & $\begin{array}{l}\text { Walle, } \\
\text { group } 1\end{array}$ & $18(86)$ & $\begin{array}{l}\text { Not } \\
\text { reported }\end{array}$ & Not reported & $17(81)$ & Not reported & \multirow{2}{*}{$\begin{array}{l}\text { Early eculizumab initiation resulted in renal recovery improvement. Showing } \\
\text { the importance of quick diagnosis and treatment of patients with aHUS. }\end{array}$} \\
\hline 2 & $\begin{array}{l}\text { Walle group } \\
2\end{array}$ & $42(55)$ & $\begin{array}{l}\text { Not } \\
\text { reported }\end{array}$ & Not reported & $36(47)$ & Not reported & \\
\hline 3 & Fakhouri & $40(98)$ & 77\%-97\% & $30(73)$ & $22(54)$ & Meningococcal infections $=2$ & $\begin{array}{l}\text { Results show the advantages of eculizumab in adult aHUS patients where } \\
\text { hematologic, renal, and quality-of-life parameters improved, and dialysis } \\
\text { discontinuation and transplant protection were reported. }\end{array}$ \\
\hline 4 & Sheerin & Not reported & 41 & Not reported & Not reported & Not reported & $\begin{array}{l}\text { They discussed the experience of a providing a locally delivery national } \\
\text { specialized service in England for the assessment and treatment of aHUS } \\
\text { patients. The patients could therefore receive eculizumab when they needed } \\
\text { it for the whole period of treatment. }\end{array}$ \\
\hline 5 & Greenbaum & $21(95)$ & $21(95)$ & $14(64)$ & $19(86)$ & $\begin{array}{l}\text { Patients with treatment-emergent adverse events related to } \\
\text { eculizumab=9 (Including abdominal discomfort, agitation, } \\
\text { alopecia, diaper dermatitis, diarrhea, dyspepsia, ear infection, } \\
\text { eye discharge, eczema, fungal infection, headache, injection site } \\
\text { rash, muscle spasms, nasopharyngitis, pain, rash, respiratory } \\
\text { syncytial virus infection, viral respiratory tract infection, viral } \\
\text { upper respiratory tract infection) }\end{array}$ & $\begin{array}{l}\text { The stated the efficacy and safety of eculizumab for aHUS pediatric patients, } \\
\text { and proposed an immediate eculizumab initiation after diagnosis in children. }\end{array}$ \\
\hline 6 & $\begin{array}{l}\text { Licht } 1 \\
2 \text { year }\end{array}$ & $15(88)$ & $15(88)$ & $13(76)$ & $10(59)$ & $\begin{array}{l}\text { Serious adverse events: Accelerated hypertension }=2, \\
\text { Asymptomatic, bacteriuria }=1, \text { Hypertension }=1\end{array}$ & \multirow{6}{*}{$\begin{array}{l}\text { Eculizumab had no new safety concerns or meningococcal infections. Clinica } \\
\text { benefits were observed sooner by eculizumab treatment of aHUS which } \\
\text { maintained during a 2-year follow-up. }\end{array}$} \\
\hline 7 & $\begin{array}{l}\text { Licht } 1 \\
1 \text { year }\end{array}$ & $15(88)$ & $15(88)$ & $13(76)$ & $9(53)$ & $\begin{array}{l}\text { Serious adverse events: Accelerated hypertension }=2 \text {, } \\
\text { Asymptomatic bacteriuria }=1 \text {, Hypertension }=1\end{array}$ & \\
\hline 8 & $\begin{array}{l}\text { Licht } 1 \\
26 \text { weeks }\end{array}$ & $14(82)$ & $15(88)$ & $11(65)$ & $8(47)$ & $\begin{array}{l}\text { Serious adverse events, Accelerated hypertension }=1 \text {, } \\
\text { Hypertension }=1\end{array}$ & \\
\hline 9 & $\begin{array}{l}\text { Licht } 2 \\
2 \text { year }\end{array}$ & $18(90)$ & $19(95)$ & $11(55)$ & $8(40)$ & $\begin{array}{l}\text { Serious Adverse events, Influenza=1 (5) } \\
\text { Peritonitis= } 1(5) \text {, Venous sclerosis at infusion site }=2(10)\end{array}$ & \\
\hline 10 & $\begin{array}{l}\text { Licht } 2 \\
1 \text { year }\end{array}$ & $18(90)$ & $17(85)$ & $7(35)$ & $3(15)$ & $\begin{array}{l}\text { Serious adverse events Influenza=1 (5), Peritonitis= } 1(5) \text {, } \\
\text { Venous sclerosis at infusion site }=2(5)\end{array}$ & \\
\hline 11 & $\begin{array}{l}\text { Licht } 2 \\
26 \text { weeks }\end{array}$ & $18(90)$ & $16(80)$ & $5(25)$ & 1 (5) & $\begin{array}{l}\text { Serious Adverse events, Peritonitis= } 1 \text { (5) } \\
\text { Venous sclerosis at, infusion site }=1 \text { (5) }\end{array}$ & \\
\hline
\end{tabular}


Only in the study by Licht et al, the follow-up was 2 years, other studies had 26 weeks up to 1 year. Some disparities were seen in outcomes of the chosen studies; for example, in the study by Sheerin (2), only TMA event-free status was reported for outcome measures. Some studies such as Greenbaum (14) and Licht et al (13) reported adverse events by details. The studies by Walle et al (6) and Greenbaum et al (12) emphasized early eculizumab initiation for aHUS treatment. Fakhouri et al (11) suggested the benefits of eculizumab in the treatment of adult patients with aHUS, such as quality-of-life parameters, which are noticeable outcomes in treatment of any disease.

Sheerin et al (2) discussed the necessity of having locally available national specialized services for the investigation and treatment of patients with aHUS. They reported that such a system enabled aHUS patients to receive eculizumab when they need it (2). In the study of Macia et al (15), the authors researched eculizumab discontinuation. They showed that the reasons for treatment discontinuation include both medical and economic concerns as well as patients' request (15). That study suggested that TMA manifestations following discontinuation are unpredictable in both severity and timing (15). They indicated an evidence-based decision making, better risk stratification and valid monitoring strategies for eculizumab (15).

Nowadays, eculizumab is not administered for the treatment of aHUS in Iran. One of the main reasons is the high cost. Sheerin et al (2) discussed the necessity of having a subsidized system for aHUS patients. The findings of a systematic review conducted in 2013 (16) on the application of eculizumab in aHUS match our findings. They performed two small, uncontrolled prospective multinational, multicenter studies, and one small uncontrolled multinational, multicenter retrospective study (16). That systematic review concluded that eculizumab is clinically effective for the treatment of aHUS. They however suggested further research to evaluate eculizumab for the treatment of aHUS. In another review study conducted in 2013 (8) on the application of eculizumab, eculizumab was shown to be effective in both pediatric and adult patients (8). They presented an association between eculizumab and increased susceptibility to meningococcal infection such that the patients were recommended to receive meningococcal vaccine (8). In the study of Fakhouri et al (11), two cases with meningococcal infections were reported, but in two trials of the Licht study, no meningococcal infection case was reported. We suggest confirmation of their findings by further controlled and prospective studies.

\section{Conclusion}

Acknowledging the limitations of our research work due to the size and nature of the studies included, our systematic review shows that eculizumab is effective in the treatment of aHUS. However, further large randomized trials are recommended.

\section{Authors' contribution}

MGS, YR, ME and AO searched the data and prepared the primary draft. AA edited and finalized the paper. All authors read and signed the final manuscript. MM and $\mathrm{HN}$ contributed equally to prepare the paper.

\section{Conflicts of interest}

The authors declare no conflict of interest.

\section{Ethical considerations}

Ethical issues (including plagiarism, data fabrication, double publication) have been completely taken into account by the authors.

\section{Funding/Support}

This work is supported by a financial grant from Mashhad University of Medical Sciences.

\section{References}

1. Kavanagh D, Goodship TH, Richards A. Atypical hemolytic uremic syndrome. Semin Nephrol. 2013;33:508-30. doi: 10.1016/j.semnephrol.2013.08.003.

2. Sheerin NS, Kavanagh D, Goodship TH, Johnson S. A national specialized service in England for atypical haemolytic uraemic syndrome-the first years' experience. QJM. 2015;109(1):27-33. doi: 10.1093/qjmed/hcv082.

3. Noris M, Remuzzi G. Atypical hemolytic-uremic syndrome. N Engl J Med. 2009;361:1676-87. doi: 10.1056/ NEJMra0902814.

4. Westra D, Wetzels JF, Volokhina EB, Van den Heuvel LP, Van De Kar NC. A new era in the diagnosis and treatment of atypical haemolytic uraemic syndrome. Neth J Med. 2012;70:121-9.

5. Volokhina EB, van de Kar NC, Bergseth G, van der Velden TJ, Westra D, Wetzels JF, et al. Sensitive, reliable and easyperformed laboratory monitoring of eculizumab therapy in atypical hemolytic uremic syndrome. Clin Immunol. 2015;160:237-43. doi: 10.1016/j.clim.2015.05.018.

6. Walle JV, Delmas Y, Ardissino G, Wang J, Kincaid JF, Haller H. Improved renal recovery in patients with atypical hemolytic uremic syndrome following rapid initiation of eculizumab treatment. J Nephrol. 2017;30:27-34. doi: 10.1007/s40620-016-0288-3.

7. Chawla LS, Eggers PW, Star RA, Kimmel PL. Acute kidney injury and chronic kidney disease as interconnected syndromes. N Engl J Med. 2014;371:58-66. doi: 10.1056/ NEJMra1214243.

8. Keating GM. Eculizumab: a review of its use in atypical haemolytic uraemic syndrome. Drugs. 2013;73:2053-66. doi: 10.1007/s40265-013-0147-7.

9. Zuber J, Fakhouri F, Roumenina LT, Loirat C, FrémeauxBacchi V. Use of eculizumab for atypical haemolytic uraemic syndrome and C3 glomerulopathies. Nat Rev Nephrol. 2012;8:643-57. doi: 10.1038/nrneph.2012.214. 10. Legendre CM, Licht C, Muus P, Greenbaum LA, Babu 
S, Bedrosian C, et al. Terminal complement inhibitor eculizumab in atypical hemolytic-uremic syndrome. N Engl J Med. 2013;368:2169-81. doi: 10.1056/NEJMoa1208981.

11. Fakhouri F, Hourmant M, Campistol JM, Cataland SR, Espinosa M, Gaber AO, et al. Terminal Complement Inhibitor Eculizumab in Adult Patients With Atypical Hemolytic Uremic Syndrome: A Single-Arm, Open-Label Trial. Am J Kidney Dis. 2016;68:84-93. doi: 10.1053/j. ajkd.2015.12.034.

12. Greenbaum LA, Fila M, Ardissino G, Al-Akash SI, Evans J, Henning P, et al. Eculizumab is a safe and effective treatment in pediatric patients with atypical hemolytic uremic syndrome. Kidney Int. 2016;89:701-11. doi: 10.1016/j.kint.2015.11.026.

13. Licht C, Greenbaum LA, Muus P, Babu S, Bedrosian CL,
Cohen DJ, et al. Efficacy and safety of eculizumab in atypical hemolytic uremic syndrome from 2-year extensions of phase 2 studies. Kidney Int. 2015;87:1061-73. doi: 10.1038/ ki.2014.423.

14. Greenbaum LA. Atypical Hemolytic Uremic Syndrome. Adv Pediatr.2014;61:335-56.doi:10.1016/j.yapd.2014.04.001.

15. Macia M, de Alvaro Moreno F, Dutt T, Fehrman I, Hadaya K, Gasteyger C, et al. Current evidence on the discontinuation of eculizumab in patients with atypical haemolytic uraemic syndrome. Clin Kidney J. 2017;10:310-19. doi: 10.1093/ckj/ sfw115.

16. Rathbone J, Kaltenthaler E, Richards A, Tappenden P, Bessey A, Cantrell A. A systematic review of eculizumab for atypical haemolytic uraemic syndrome (aHUS). BMJ Open. 2013;3:e03573. doi: 10.1136/bmjopen-2013-003573.

Copyright (c) 2019 The Author(s); Published by Nickan Research Institute. This is an open-access article distributed under the terms of the Creative Commons Attribution License (http://creativecommons.org/licenses/by/4.0), which permits unrestricted use, distribution, and reproduction in any medium, provided the original work is properly cited. 